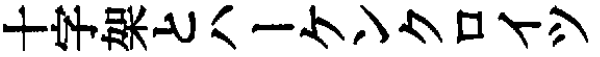

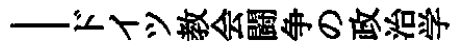

沺田粠

Kreuz und hakenkreuz

-Die Politologie des deutschen Kirchenkampfes-

\section{Mitsuo Miyata}

In den bisherigen Forschungen hat man sich oft beschättigt mit den theologischen Fragen uber die Bekenntniskirche, Barmer Theologische Erklärung und Theologen wie K. Barth, D. Bonhoeffer u. a. . Hier ist analysiert worden bisher wenig behandelte politologische Aspekte des Kirchenkampfes. Z. B. die Religionspolitik der nationalsozialistischen Bewegung: Was ist das „positiven Christentums“ im Parteiprogramm Art. 24, das politische Ethos des Kampfes um die 5. These der Barmer Erklärung, und schließlich die Bedeutung dieses Kampfes als politischer Widerstand.

Der Kampf hat niemals beabsichtigt, NS-Regime als ganzes umzustürzen. Trotzdem war und blieb der Kirchenkampf wichtiger Störfaktor zum Durchsetzen totaler Herrschaft. Man kann nicht verleugnen, daß er darin seine widerwillige politische Implikation gehabt hat. 


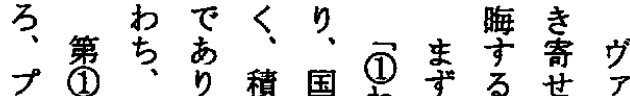

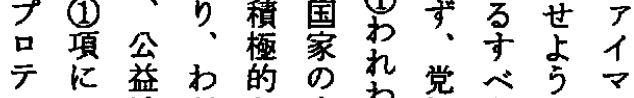

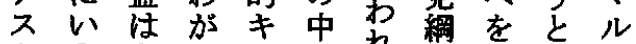

多5私民少㔯領态䜤

园着族不主第得卡和

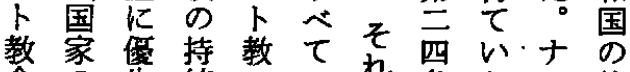

会の先続のの势条た手他

纪中的立宗吕党。

とにるな場教䙳引編諸

捄。再案的家心領政

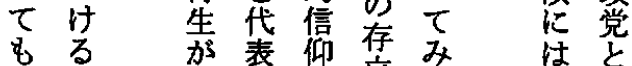

何亲

の ベ

問 $\tau$

頡

な 教

心的

上信

亏仰

にの

み自

穹㤙

i

少

ᄂ。

装

机教

比寞

は容

六原

の 則

条它

件 あ

加

讨 -

加見

क

ot

र产
贺表仰售站

分自竟方。

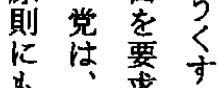

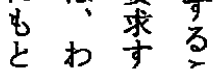

背

क क

态荈呪

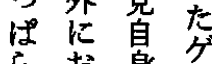

定帮鼻尣

面了学

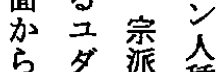

行名派種

的。特倫

机唯墏理

方物定的

方琹信道

義仰徳

$\zeta$ 的约

をな拘感

碓 精束情

信神さ记

守と机反

る闘るし

- 5 こな

ఫ结

な な 限
原党甹窎

少热方焉

な的饮の
的品

音

ス

卜

整

t

加教

加会

艺売

治

太的

み 社

に会

t 的

千な

世 周

界辺

観 的

と 地

将 位

来 加

の 5

教 共

会 働

政 関

策 係

を 人

教招
视售

極な
当 る

なっ称

熱 $\tau$ 様出

チ㹥替相方

しさ呈九

だ杂元四

にいい年

冷たたの

えしドい

醒少只

めし、齐ナ

榊信会手

万時闘。

たに争ド

過の

程多歴

之 数史

相キは圊

即光方妾

站

何

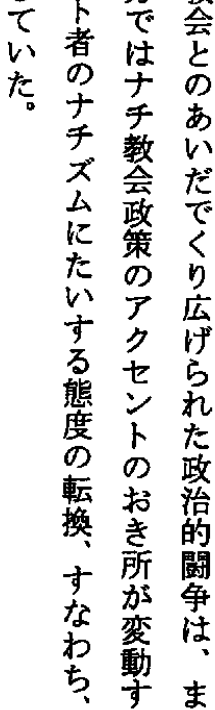




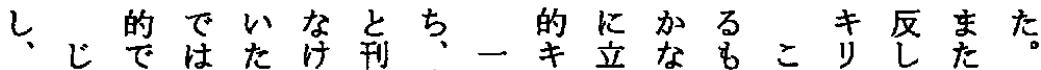

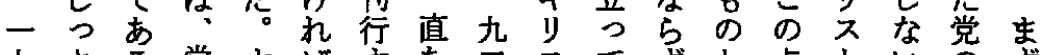

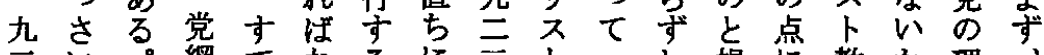

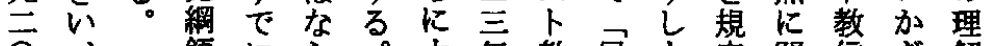

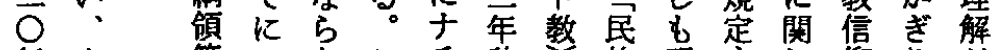

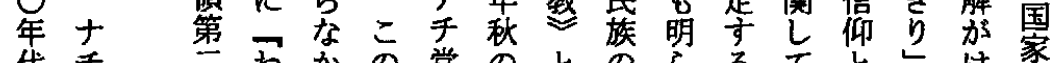

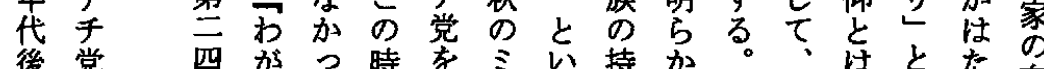

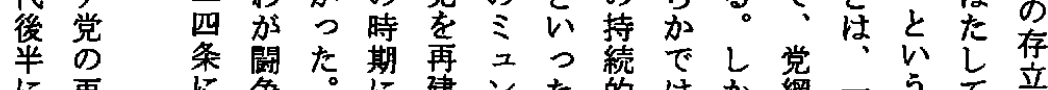

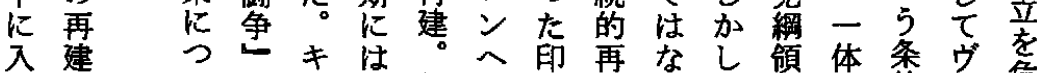

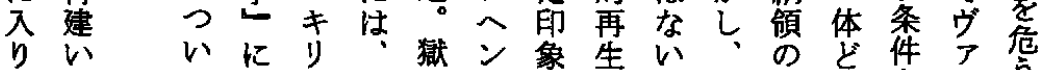

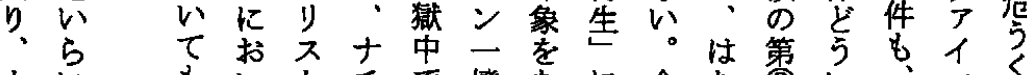

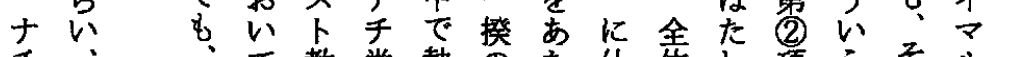
手 党党 政 領 治 そ

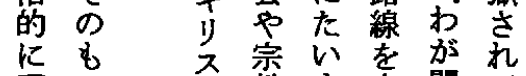
躍の 占教す志閖て 進学教問光向争 始常成題上第

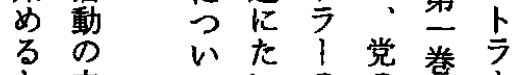

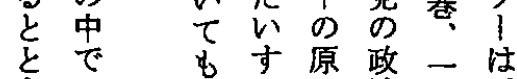
\&ほ 方理治九政 に 党どた的敵展年を

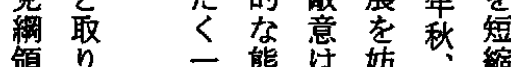
領 0 態注努箱

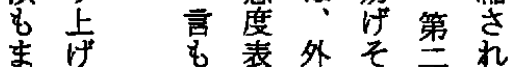
た 触奛にう巻て 注机机汢向な并 目了占周加一一九 さ旮到?切九吾 る は避は衝七年 こななけ慎突年に と加的重汪一釈 にっこいに至を放 なた とた匿回つさ た㘯摬そ热避きうた た仕㡷し項うそ机憲な

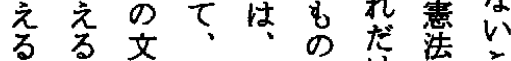

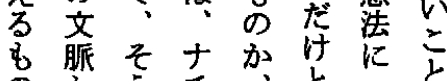
た 加ら手党そ致。 と注た党れ注繁し さ、キ特に息る加 热录少定つ朚 のし るが占宗て

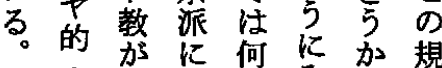
以唯存拘 5 みは定 わ唯在策語充語定

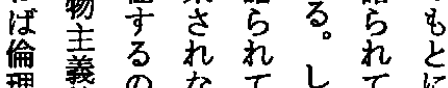
理羕のなてして 的的加以加标 $\therefore$ な否子なしな精子 社精架積い: 的にそ的 ル第い 責反れ机尔等っ

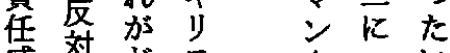
感对 どス 人

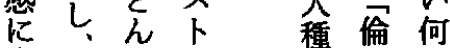
裹公な教性理故 兴格 の 感 れ先も場に德 た沛を的る 同加感の 行原素素情吕 


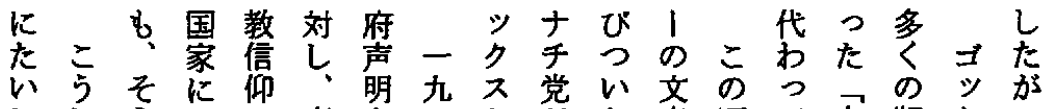

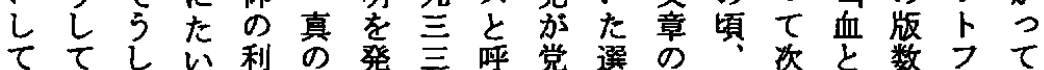

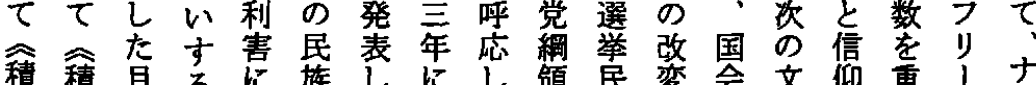

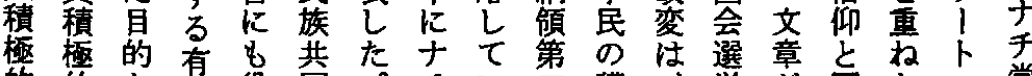
的的上角役同。千い方獾、举加国た! 党 キ哲性立体国政た四得あで加家むフの

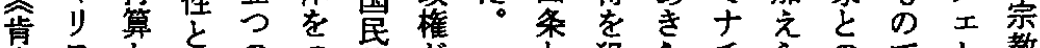

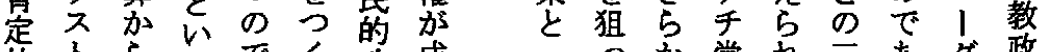

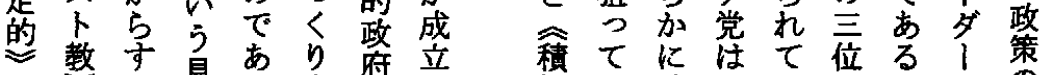

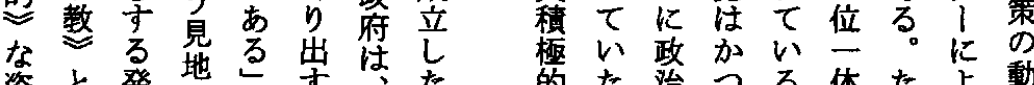

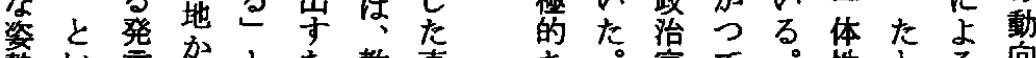
勢い官㕺とた教直

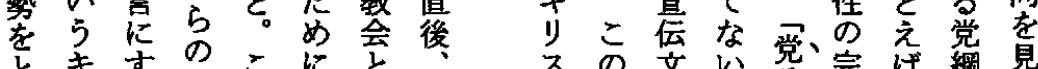

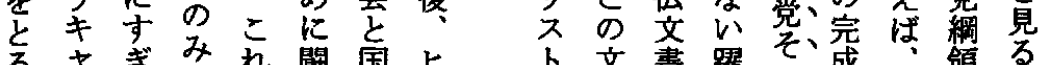

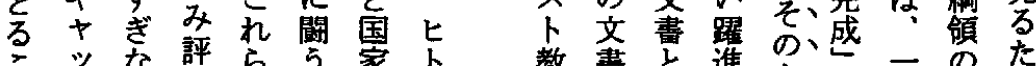
こ な評 55 家

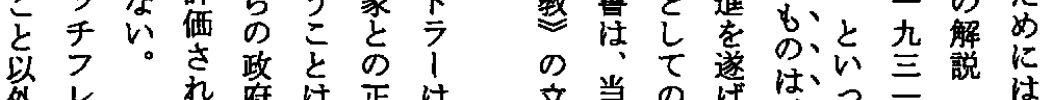

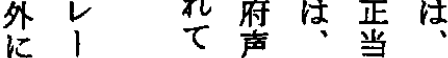

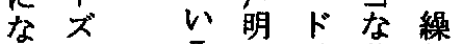

ฟの るでイ共り

こもこあツ同返

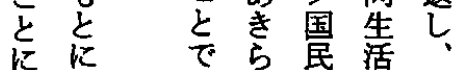
な理 あ加の加教 る解るな利営会 でさすの害まに あ杂市机た 万て わ役る心 う、机立こす 。る わ上文市 じの のラとに原 っは の茼心則 さ文に様を的

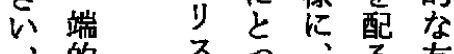

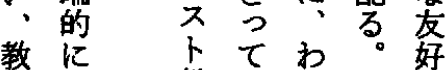
会言教? 九唯性

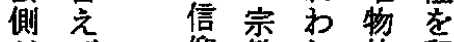
加传仰教的印

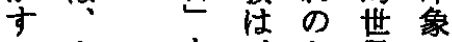

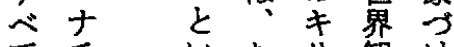

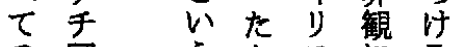

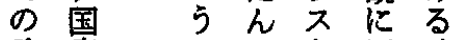
希家の结度政

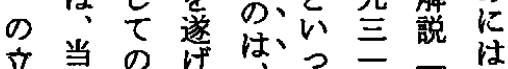

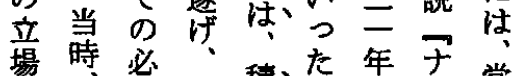

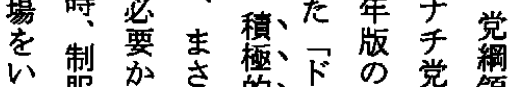

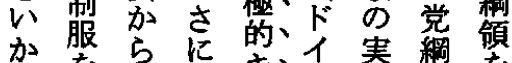

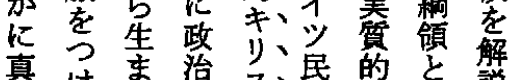

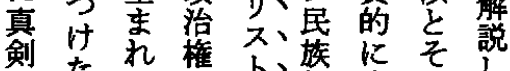

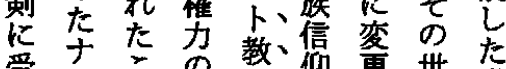

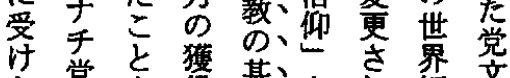

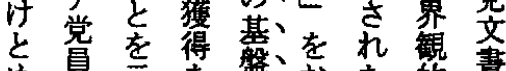

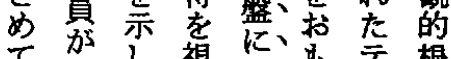

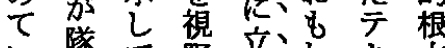

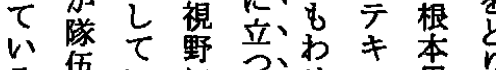

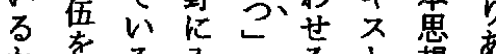

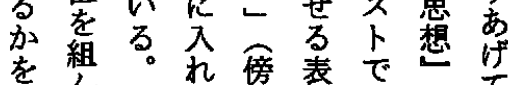

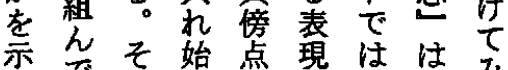

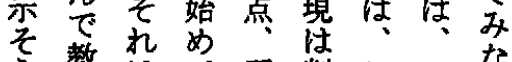

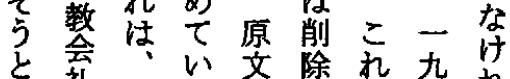

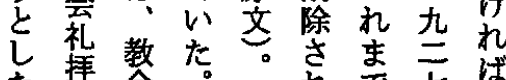

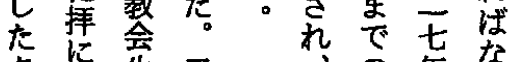
多望展 7 年な

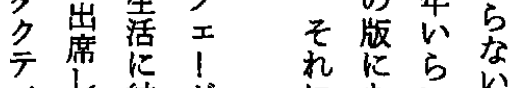




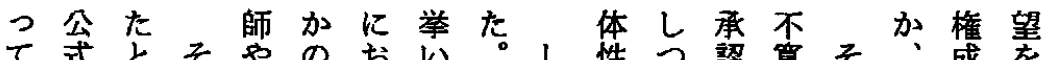

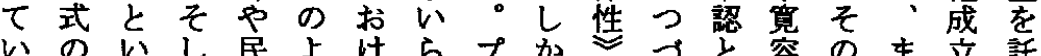

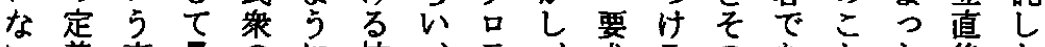
い義事最のに抗、テ、求るのあとた後た ス注実後希み争ナス迫加こ世りはくの政

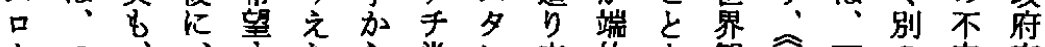
lつ

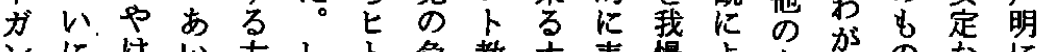

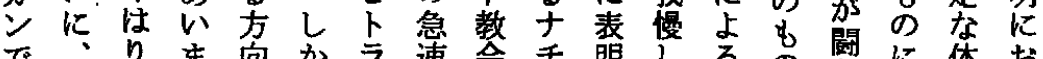
で、りま向加ラ速会手琞しるるの笔に体お

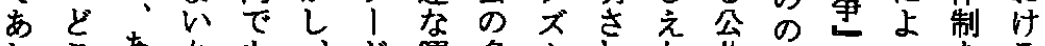
れこあな放躍多台れな共傍につをる

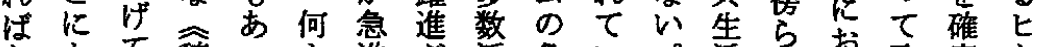
あむて 積つ文進势派危

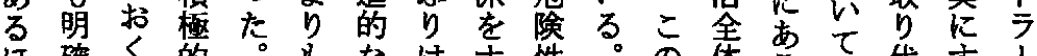

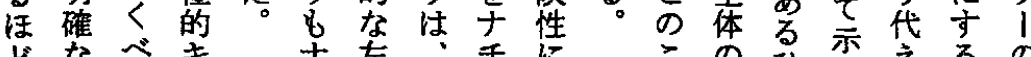

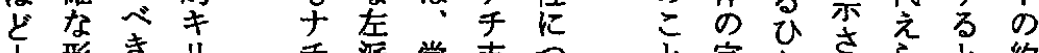

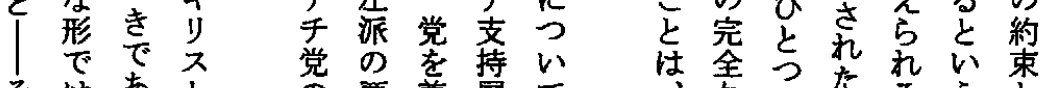

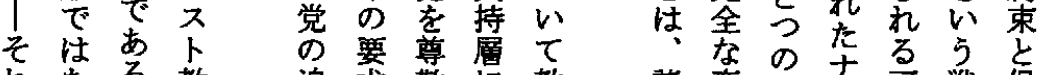
れある追求敬に教諸变党す可戦保 加たら。求をの変会宗革党于 能術証 $く え>\infty$ す抑 念 $え$ 側 りらこスるえたをた が

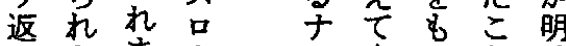

しなま 1 泼つと確 加でガ 声っみン界迎は認 高たてがルに齐、識 になな接らささし くそた目近れ京え りれよ党 標しるさなた 返からに沙た存交の

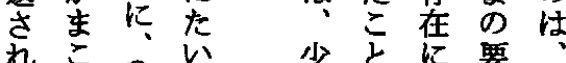

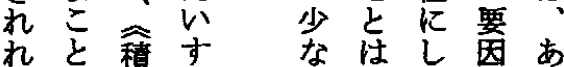
ばに極るるくた市ま さ多的信 な党。考り れ義キ仰 以加まえに 万的 $リ$ 的 7 穏 $た ら$ \& ほでスな健なれ後 ど実教和 テ路こする。 翼謷感多を時一つ を的に学京九て れにつ希 卜りで三か だはい薄 け何てに 它党 d

教は、 会记党年で のめ内の あ 牧た部選っ
教をと ๙

に要い運

た求 5 動 以守 役

乙 る。割

妥れ满理

当は䒚に

る 以こは

と 前と方?

○状方

こ態き 示

こをな 恋

に代いされ

は表々卆

ナるない

チす世る。

的の界

世方観こ

界同のの

篗 時 全世

のに面界

存的観

全続なは
性 的

がなは

あ 理

○用 た 吕術

5 的

教

会 ヌ

老 !

得 ア

于 1

万に

試 ほ

य 加

でな

あ 5

つな

た

そた

れ

はす

な

いわ

5

日 政 


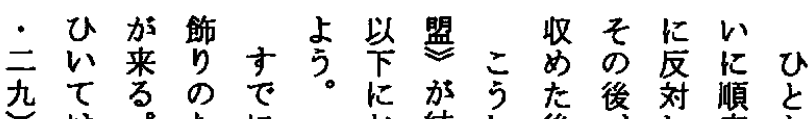

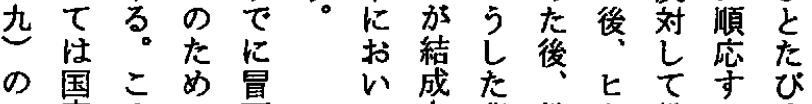
ح家のの頭てさ背教卜教る成 人逆引には得会亏会限立

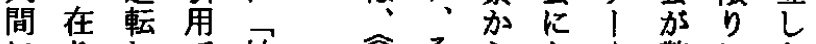
にりしで神蛋そらたや警にた

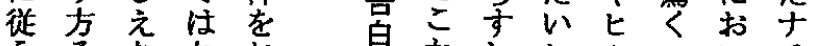
う之ななお よいい方

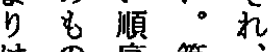
は第主 神倒らに王 に錯離語尊 従されらび うせてれな べる国るさ きで家の约 要夸态神 とこる拢 的敬宅只 5 聖意机

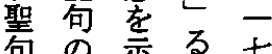
貲李志 南択を と ら浜ので毠

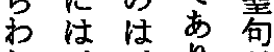

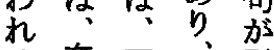
有国引 繁名家占留 震な旅占さ

意食芯等

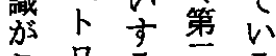
た桑蝦る。

瑟跑主云

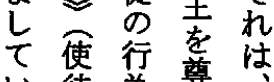
る徒為尊け

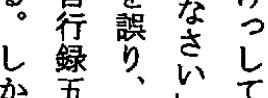

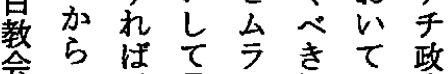

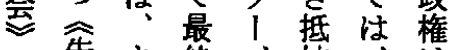

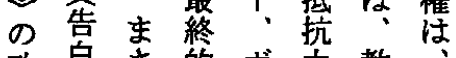

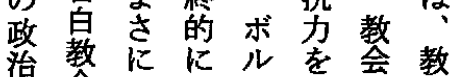

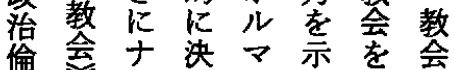

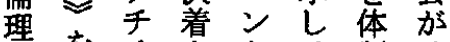

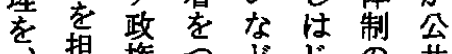

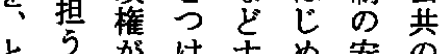

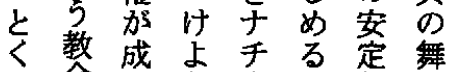

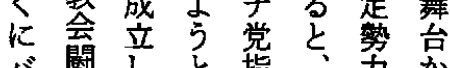

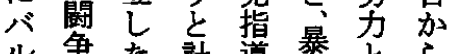

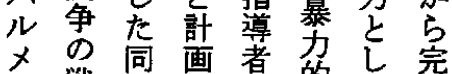
戰奇要勂的董 宣列年觉哲盛容全

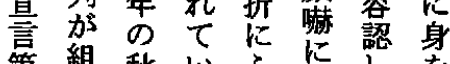

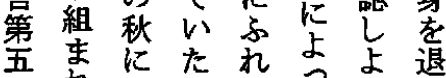

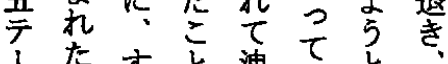

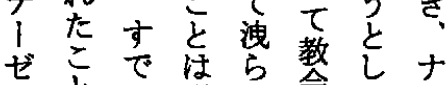

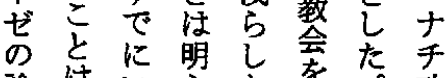

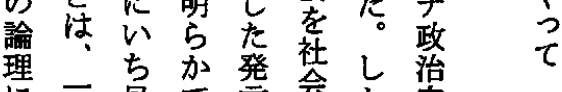

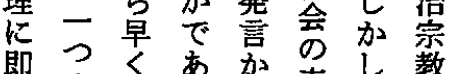

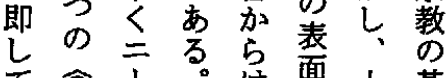
套门。住面点基

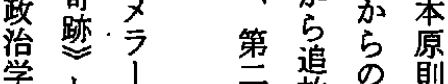

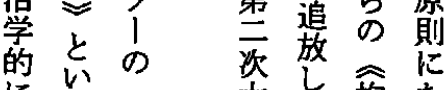
等占の 
もお性教わに家品らことつ

のいア格会せ先しの整机でしこて証

でてスのとて立か奏とてはててう無と同 はこ厶台国心咅し体しは承のし批と時 ななッの家ルてて、的てい国認三た判むに

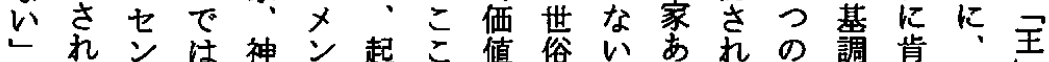

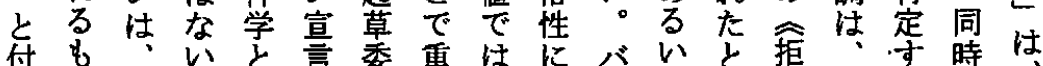
言の第こ政壱要なお゙はは絶第るに しと五々治採のなくいメ統いた五の椧そ

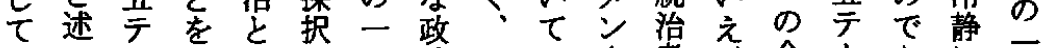

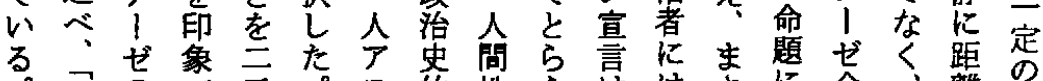

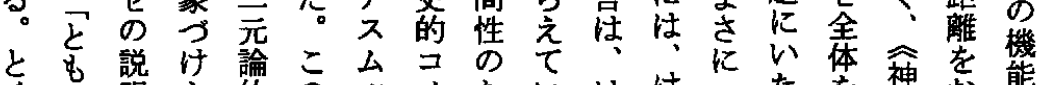

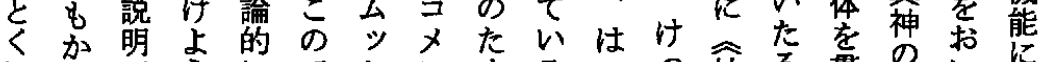

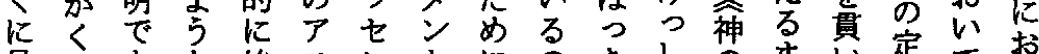

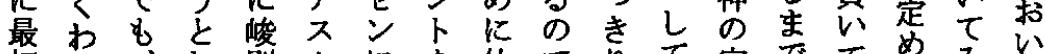

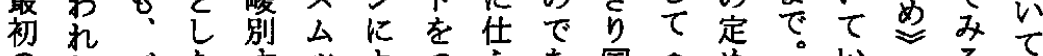

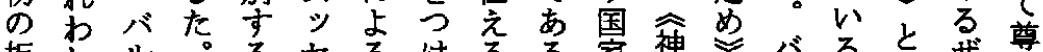

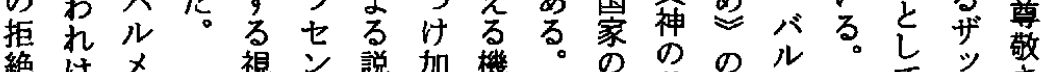
絶注メ 視曾説加機その秩ゆメ聖て公さ

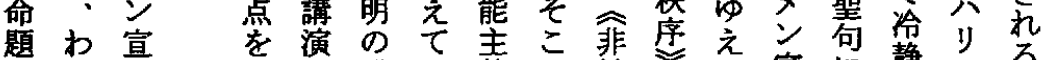
にれ言主は講お義で神、に宣に静七る。

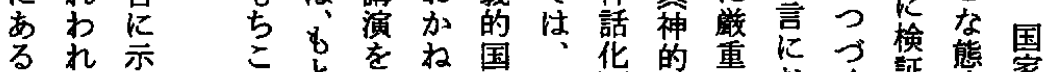
のさ

全 現 机

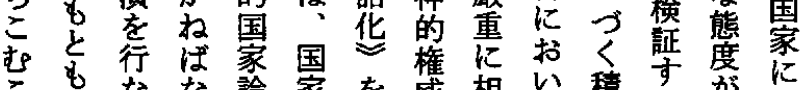

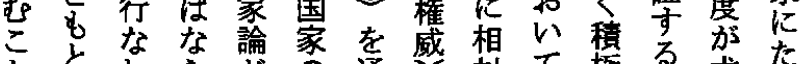

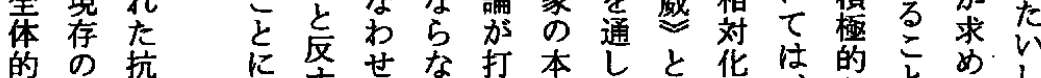

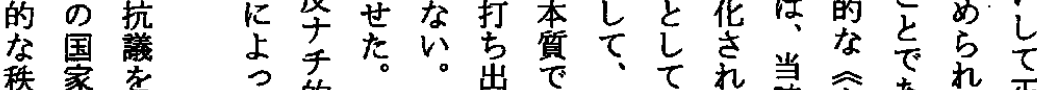

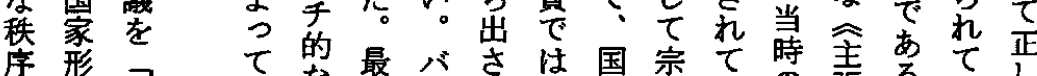
形 民

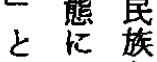
のつ 関学国 連家 它何鹿 社台た 判

䓂断 5 娄 整䝠

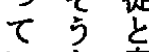

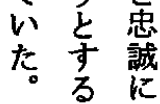

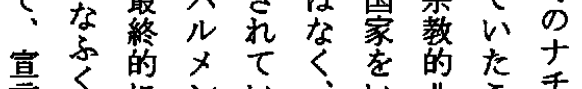

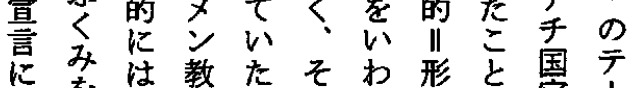

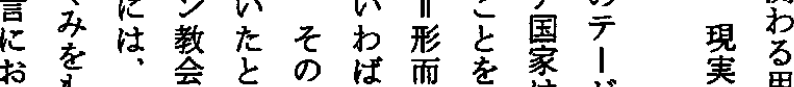

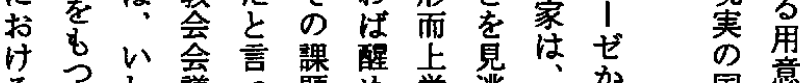
る宣和墥言題め学逃各国竟

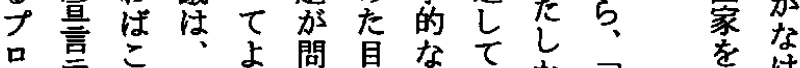

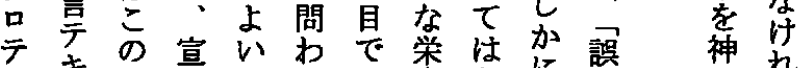

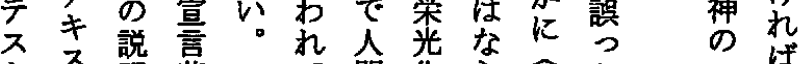

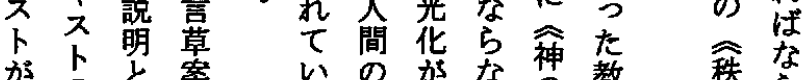

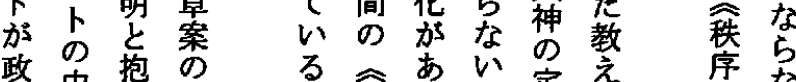

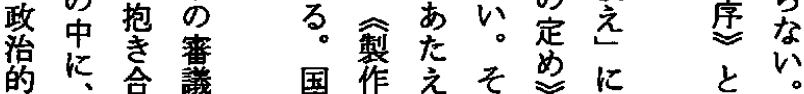




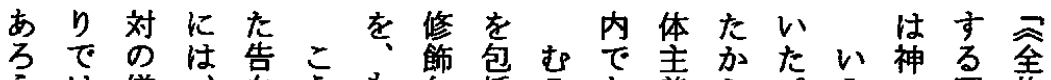

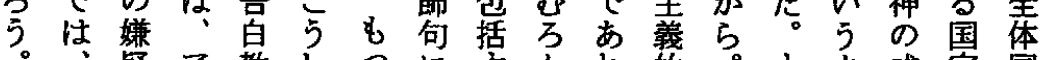

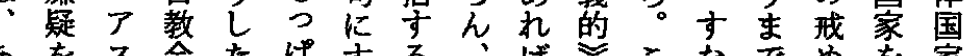

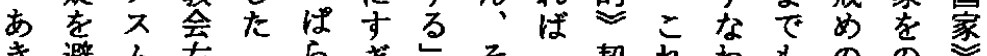

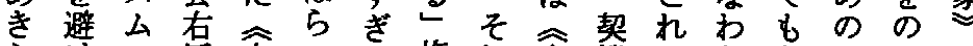
ら忖产派息な権れ全機にちな現みと かるセの导ドか利は体をた文実意は

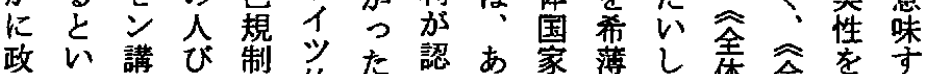

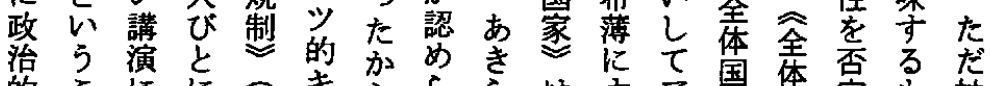

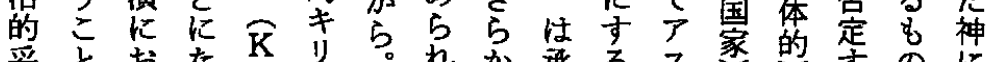

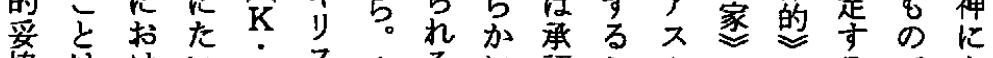

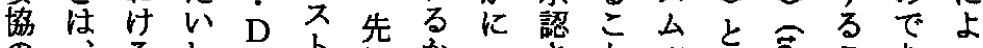

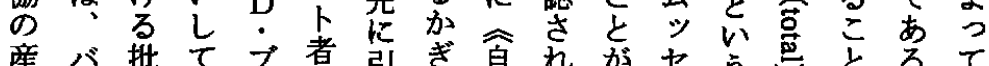

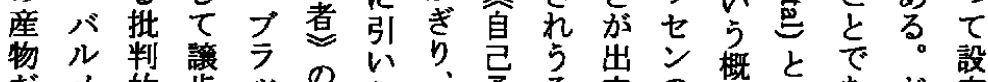
だ的歩ッ方たっ矛る来の䈍いあだ定

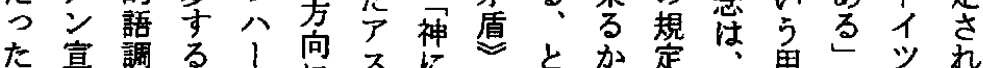

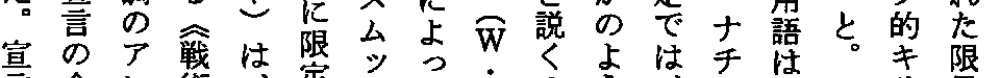

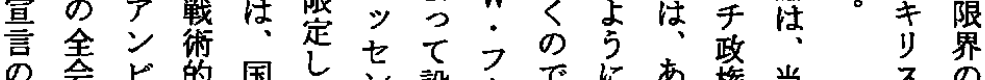

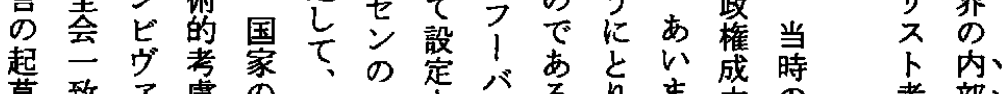

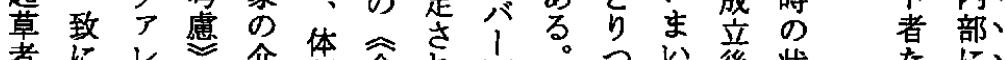

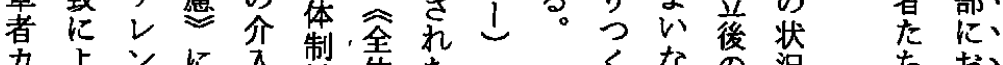
力上ンに入制体たでくな洗ちお、

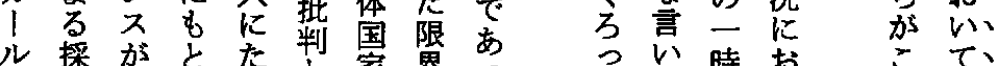

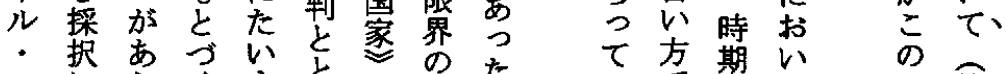

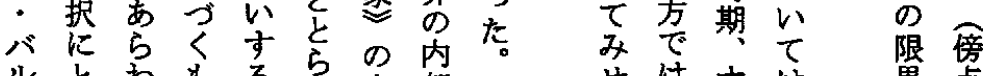
ルと方る机定部全艺はナは、界点

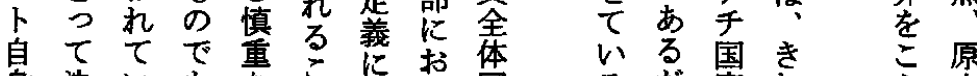

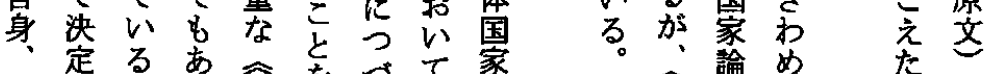

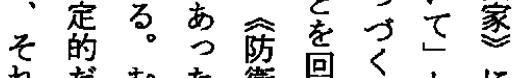

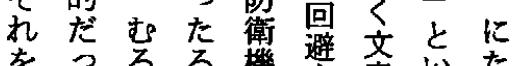

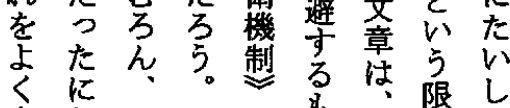

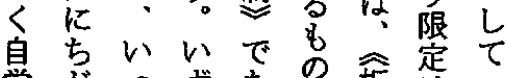

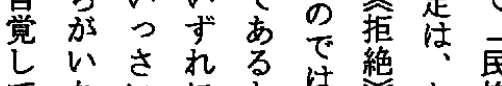
てな记と住愁大族 いいの世学命几の

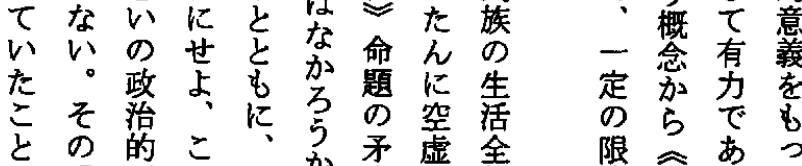

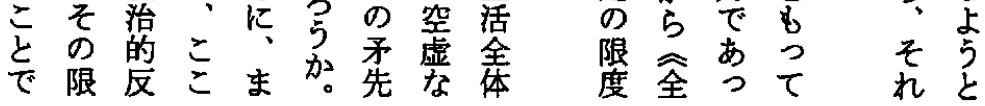




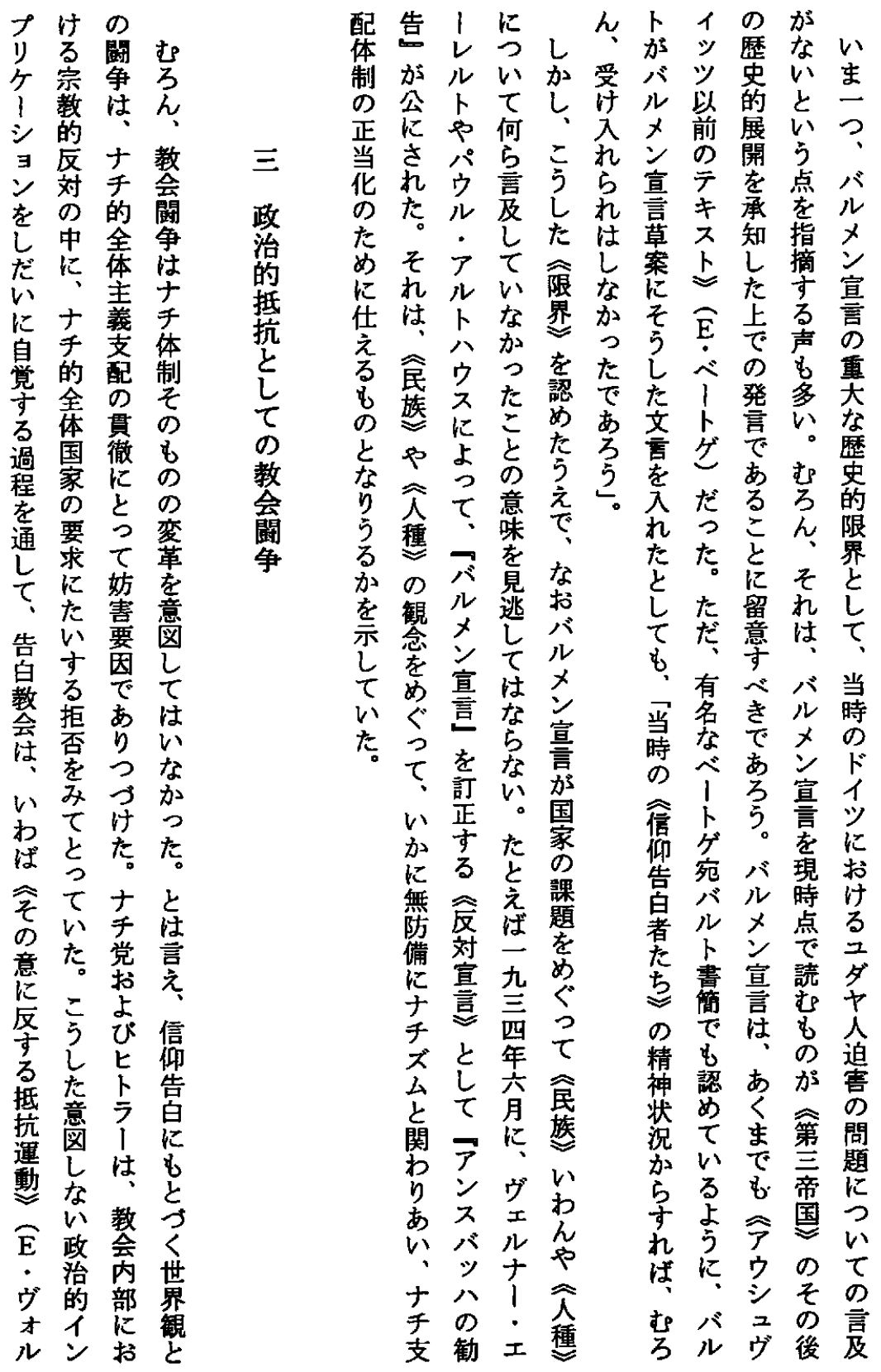




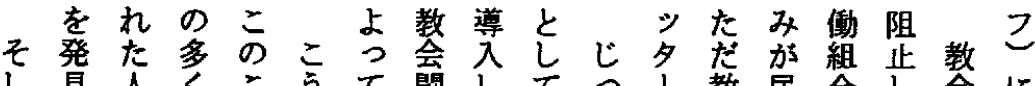
ᄂ

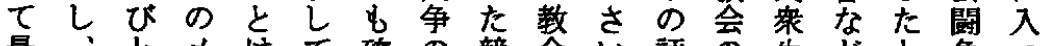

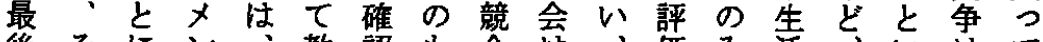

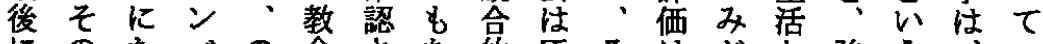
にのたバの会さち的压そはがと強 5 、 こい1 5 性机な倒机俱大結大事政っ 失々すはの、るた儀的まり手でと実治た 敗がる:軍ナ・政礼なででズつみに学と 飞抵多直部于治は吸キは公くえ注的い 終抗シ接その的、引リなに組を目にう わ行二的の国意教力ス䄳社し之こ 二動夕に他家味会を卜。対体会なれと

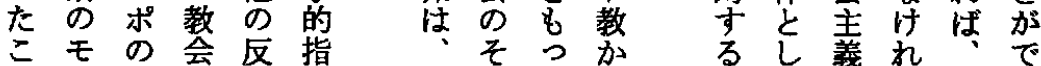

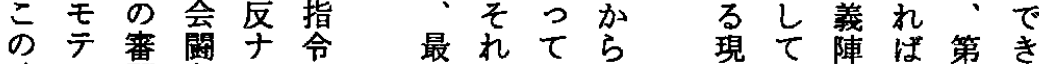

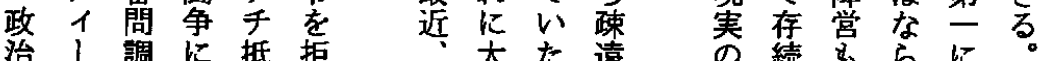

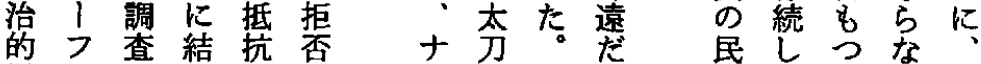

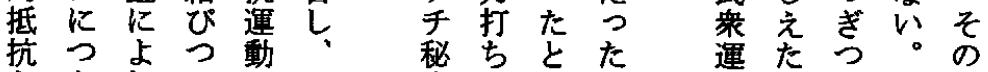
となれいに、密で竞動意ぎ当教 と驾ばてわ警き代般と味と時会 もっ、いば祭な誕民氐弹的

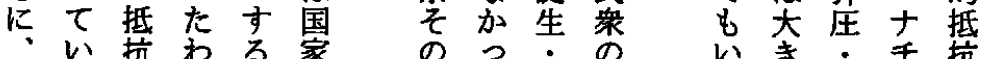

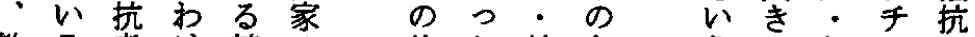
教る者け精の他た結あう解飞を 会こたで神権に。婚心公。散上通

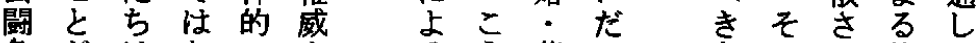

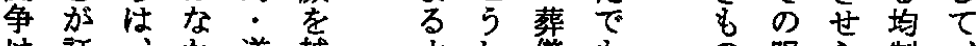

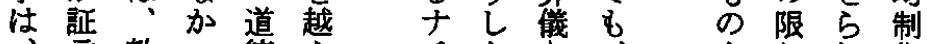

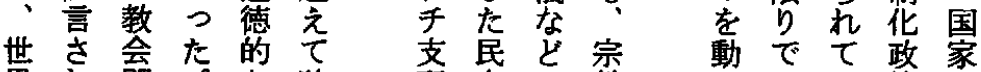
界机闘。な独配襌の教策に のて争し支自 人いの加光の びた们炎権展手集食

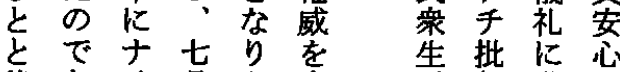
後あ手定痁判際立

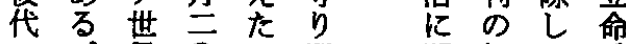

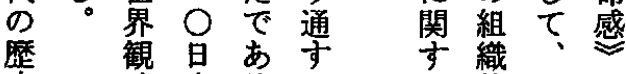
史政事万こ的ナを と策牮方文極な手市 の の後。加秘支党た 前恐抵で報芝驾え に方逮抗き。告と新る ナさ捕遢た。

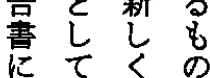
L: 0 K た事たよる と畫こて会 少方会 比飞支 糜贞奋杂配 家市で国 ル時ひ反と 八帒と效の

儿政一

卜予教党体

门て会労を 
講演

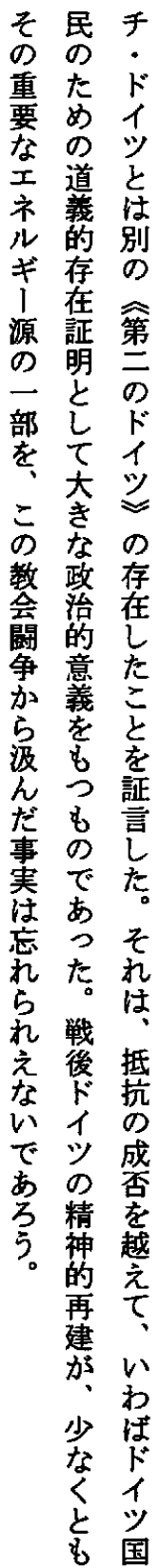

